\title{
Improving Proton Relaxivity of Dendritic MRI Contrast Agents by Rigid Silsesquioxane Core
}

\author{
By Kazuo TANAKA, ${ }^{1}$ Narufumi KITAMURA,${ }^{1}$ Kensuke NAKA,${ }^{2}$ Masahito Morita, ${ }^{3}$ \\ Toshiro INUBUSHI, ${ }^{3}$ Moeko CHUJO,${ }^{4}$ Masaya NAGAO, ${ }^{4}$ and Yoshiki CHUJO ${ }^{1, *}$
}

We report that the cubic octameric polyhedral oligomeric silsesquioxanes (POSS)-core dendrimers, novel gadolinium (Gd) chelators, enhanced the proton relaxivity to $\mathrm{Gd}^{3+}$. The stability of the $\mathrm{Gd}$ complex with POSS(G1.5) was similar to those of DOTA and DTPA. From the MTT assay with the primary hepatocytes, the cytotoxicity of $\left[\mathrm{Gd}_{2} \mathrm{POSS}(\mathrm{G} 1.5)\right]^{2-}$ showed lower than that of the $[\mathrm{Gd}(\mathrm{DOTA})]^{-}$complex. The detection limits were approximately 100 -fold improved than those of DOTA and DTPA-Gd complexes in the MR images.

KEY WORDS: MRI / Contrast Agent / Silsesquioxane / Dendrimer / Gadolinium / POSS /

Magnetic resonance imaging (MRI) is one of powerful diagnostic tools in modern clinical medicine, and paramagnetic complexes, which have the ability to enhance the proton relaxation rate of water tissue, are used as contrast agents for improving sensitivity and specificity. The most commonly used positive contrast agents nowadays are thermodynamically and kinetically stable low molecular weight gadolinium compounds based on a polyaminocarboxylate motif (linear DTPA and cyclic DOTA respectively) for suppressing the toxicity of $\mathrm{Gd}^{3+}$ and accelerating the proton relaxation rate of water tissue coordinated to $\mathrm{Gd}^{3+} .{ }^{1}$ Since contrast agents with high relaxivity can be detected at lower doses, the relaxation mechanism and a number of predominant parameters to achieve sufficient $T_{1}$ change have been studied. ${ }^{1}$

Macromolecules are considerable useful for constructing highly-sensitive and functional contrast agents due to the enhancement of relaxivity by the effect of the increased molecular weight which would reduce the rotational tumbling time of the molecule. Numerous high molecular weight complexes have been developed, and many researchers have extensively studied about not only their relaxation mechanisms but also toxicity and clearance system in living bodies for practical usage. ${ }^{2}$ In contrast, there is a few reports that mentioned the effect of the core on relaxivity in dendritic chelators. ${ }^{3}$ To evaluate the contribution of the structural characteristics on the relaxivity, it is expected to provide new strategy for molecular design of highly-sensitive contrast agents as well as the sophistication of previous products.

Herein, we report cubic octameric polyhedral oligomeric silsesquioxanes (POSS)-core dendrimers ${ }^{4}$ used as chelators with $\mathrm{Gd}^{3+}$ ions for highly-sensitive positive MRI contrast agents. The relaxivity measurements revealed that the POSS core can enhance the proton longitudinal relaxation of water tissue in the dendrimers. In addition, compared to the $\mathrm{Gd}$ complexes with DTPA and DOTA, the observed detection limits of POSS-core dendrimers can be improved approximately 100 -fold in the MR image.

\section{Experimental}

\section{General}

${ }^{1} \mathrm{H}$ NMR and ${ }^{13} \mathrm{C}$ NMR spectra were measured with JEOL EX-400 $\left(400 \mathrm{MHz}\right.$ for ${ }^{1} \mathrm{H}$ and $100 \mathrm{MHz}$ for $\left.{ }^{13} \mathrm{C}\right)$ spectrometer. ${ }^{29} \mathrm{Si}$ NMR spectra were measured with JEOL JNM-A400 $(80 \mathrm{MHz})$ spectrometer. Coupling constants ( $J$ value) are reported in hertz. The chemical shifts are expressed in ppm downfield from tetramethylsilane, using residual chloroform ( $\delta=7.24$ in ${ }^{1} \mathrm{H}$ NMR, $\delta=77.0$ in ${ }^{13} \mathrm{C}$ NMR) as an internal standard. Masses of dendrimers were determined with an ESI mass spectroscopy or a MALDI-TOF mass spectroscopy (acceleration voltage $21 \mathrm{kV}$, negative mode) with DHB (2,5dihydroxybenzoic acid) as a matrix.

\section{POSS(G1.0) (1) ${ }^{5}$}

(3-Aminopropyl)triethoxysilane $(100 \mathrm{~mL}, 0.427 \mathrm{~mol})$ and $35-37 \% \mathrm{HCl}(135 \mathrm{~mL})$ in $\mathrm{MeOH}(800 \mathrm{~mL})$ produced $\mathbf{1}$ as a white precipitate after $2 \mathrm{~d}$ at room temperature. The crude product was obtained after filtration, washing with cold $\mathrm{MeOH}$, and drying. The product was spectroscopically pure in $30 \%$ yield $(18.8 \mathrm{~g})$. Recrystallization from hot $\mathrm{MeOH}$ afforded $\mathbf{1}$ (4.29 g, $3.66 \mathrm{mmol}, 7 \%)$ as a white solid. ${ }^{1} \mathrm{H}$ NMR $\left(\left(\mathrm{CD}_{3}\right)_{2} \mathrm{SO}\right.$, $\left.25^{\circ} \mathrm{C}\right): \delta 8.23(\mathrm{~s}, 24 \mathrm{H}), 2.76(\mathrm{t}, 16 \mathrm{H}), 1.71(\mathrm{~m}, 16 \mathrm{H}), 0.72(\mathrm{t}$, $16 \mathrm{H}) .{ }^{13} \mathrm{C} \mathrm{NMR}\left(\left(\mathrm{CD}_{3}\right)_{2} \mathrm{SO}, 25^{\circ} \mathrm{C}\right): \delta 40.53,20.13$, and 7.96 . ${ }^{29} \mathrm{Si} \mathrm{NMR}\left(\left(\mathrm{CD}_{3}\right)_{2} \mathrm{SO}, 25^{\circ} \mathrm{C}\right): \delta-66.4(\mathrm{~s})$.

\footnotetext{
${ }^{1}$ Department of Polymer Chemistry, Graduate School of Engineering, Kyoto University, Katsura, Nishikyo-ku, Kyoto 615-8510, Japan

${ }^{2}$ Department of Chemistry and Materials Technology, Graduate School of Science and Technology, Kyoto Institute of Technology, Sakyo-ku, Kyoto 6068585, Japan

${ }^{3}$ Biomedical MR Science Center, Shiga University of Medical Science, Setatsukinowa-cho, Otsu 520-2192, Japan

${ }^{4}$ Division of Integrated Life Science, Graduate School of Biostudies, Kyoto University, Sakyo-ku, Kyoto 606-8502, Japan

*To whom correspondence should be addressed (Tel: +81-75-383-2604, Fax: +81-75-383-2605, E-mail: chujo@chujo.synchem.kyoto-u.ac.jp).
} 


\section{POSS(G1.5) (2)}

To a suspension of POSS $\mathbf{1}(1 \mathrm{~g}, \quad 0.852 \mathrm{mmol})$ and diisopropylamine $(15 \mathrm{~mL}, 86.1 \mathrm{mmol})$ in DMF $(100 \mathrm{~mL})$, tertbutyl bromoacetate $(15 \mathrm{~mL}, 102 \mathrm{mmol})$ was added, and the reaction mixture was stirred at $60^{\circ} \mathrm{C}$ for $16 \mathrm{~h}$. The resulting mixture was concentrated in vacuo, and then, added to $100 \mathrm{~mL}$ of formic acid, followed by reflux for $24 \mathrm{~h}$. The reaction mixture was concentrated in vacuo, and poured into $200 \mathrm{~mL}$ of methanol. The compound 2 (240 mg, $0.136 \mathrm{mmol}, 16 \%$ ) was precipitated as a white solid; ${ }^{1} \mathrm{H}$ NMR $\left(\mathrm{D}_{2} \mathrm{O}, 400 \mathrm{MHz}\right) \delta 3.92$ (s, 32H), 3.33 (brs, 16H), 1.83 (brs, 16H), 0.80 (brs, 16H): ${ }^{13} \mathrm{C}$ NMR $\left(\mathrm{D}_{2} \mathrm{O}, 100 \mathrm{MHz}\right) \delta 161.3,50.4,48.2,26.4,9.9$ : ${ }^{29} \mathrm{Si}$ NMR $\left(\mathrm{D}_{2} \mathrm{O}, 80 \mathrm{MHz}\right) \delta-67.2$ : MALDI-TOF $\left[(\mathrm{M}+\mathrm{H})^{+}\right]$ calcd. 1811.08, found 1812.01.

\section{POSS(G2.0) (3)}

To a suspension of POSS $\mathbf{1}(1 \mathrm{~g}, \quad 0.852 \mathrm{mmol})$ and diisopropylamine $(15 \mathrm{~mL}, 86.1 \mathrm{mmol})$ in DMF $(50 \mathrm{~mL})$ ethyl bromoacetate $(9.5 \mathrm{~mL}, 86.1 \mathrm{mmol})$ was added, and the reaction mixture was stirred at $60{ }^{\circ} \mathrm{C}$ for $16 \mathrm{~h}$. The resulting mixture was concentrated in vacuo, and extracted with ethyl acetate. The organic phase was washed with brine and dried over $\mathrm{MgSO}_{4}$. The crude product of ethyl ester $(1.07 \mathrm{~g})$ as a yellow oil was obtained after evaporation. Then, the ethyl ester was dissolved in $200 \mathrm{~mL}$ of ethylenediamine, and incubated at $60^{\circ} \mathrm{C}$ for $24 \mathrm{~h}$. The reaction mixture was concentrated in vacuo, and washed with diethyl ether. The white solid 3 (1.30 g, $0.523 \mathrm{mmol}, 61 \%)$ was precipitated in methanol $(100 \mathrm{~mL})$ by adding $35-37 \% \mathrm{HCl}$ (10 mL); ${ }^{1} \mathrm{H}$ NMR $\left(\mathrm{D}_{2} \mathrm{O}, 400 \mathrm{MHz}\right) \delta 4.18$ (br, 32H), 3.53 (brs, $32 \mathrm{H}$ ), 3.33 (brs, 16H), 3.14 (brs, 32H), 1.75 (brs, 16H), 0.68 (brs, $16 \mathrm{H}):{ }^{13} \mathrm{C} \mathrm{NMR}\left(\mathrm{D}_{2} \mathrm{O}, 100 \mathrm{MHz}\right) \delta 166.7,59.4,56.1$, 38.9, 36.5, 18.1, 9.9: ${ }^{29} \mathrm{Si} \mathrm{NMR}\left(\mathrm{D}_{2} \mathrm{O}, 80 \mathrm{MHz}\right) \delta-67.4$ : MALDI-TOF $\left[(\mathrm{M}+\mathrm{H})^{+}\right]$calcd. 2484.41, found 2484.97 .

\section{POSS(G2.5) (4)}

To a suspension of $\mathbf{3}$ ( $1 \mathrm{~g}, 0.403 \mathrm{mmol})$ and diisopropylamine $(15 \mathrm{~mL}, 86.1 \mathrm{mmol})$ in DMF $(100 \mathrm{~mL})$, tert-butyl bromoacetate $(15 \mathrm{~mL}, 102 \mathrm{mmol})$ was added, and the reaction mixture was stirred at $60{ }^{\circ} \mathrm{C}$ for $16 \mathrm{~h}$. The resulting mixture was concentrated in vacuo, and then, added to $100 \mathrm{~mL}$ of formic acid followed by reflux for $24 \mathrm{~h}$. The reaction mixture was concentrated in vacuo, and poured into $200 \mathrm{~mL}$ of methanol. The compound 4 (1.05 g, $0.242 \mathrm{mmol}, 60 \%)$ was precipitated as a white solid; ${ }^{1} \mathrm{H}$ NMR $\left(\mathrm{D}_{2} \mathrm{O}, 400 \mathrm{MHz}\right) \delta 3.72(\mathrm{br}, 96 \mathrm{H})$, 3.56 (brs, 32H), 3.30 (brs, 32H), 3.20 (brs, 16H), 1.71 (brs, $16 \mathrm{H}), 0.67$ (brs, $16 \mathrm{H}):{ }^{13} \mathrm{C} \mathrm{NMR}\left(\mathrm{D}_{2} \mathrm{O}, 100 \mathrm{MHz}\right) \delta 175.1$, 172.1, 61.7, 61.2, 59.2, 51.5, 37.5, 20.8, 10.2: ${ }^{29} \mathrm{Si}$ NMR $\left(\mathrm{D}_{2} \mathrm{O}\right.$, $80 \mathrm{MHz}) \delta-67.4:$ ESI-TOF $\left[(\mathrm{M}+3 \mathrm{H})^{3+}\right]$ calcd. 1454.8, found 1454.8 .

\section{POSS(G3.0) (5)}

To a suspension of $\mathbf{3}$ ( $1 \mathrm{~g}, 0.403 \mathrm{mmol})$ and diisopropylamine $(15 \mathrm{~mL}, 86.1 \mathrm{mmol})$ in DMF $(50 \mathrm{~mL})$ ethyl bromoacetate $(9.5 \mathrm{~mL}, 86.1 \mathrm{mmol})$ was added, and the reaction mixture was stirred at $60^{\circ} \mathrm{C}$ for $16 \mathrm{~h}$. The resulting mixture was concentrated in vacuo, and extracted with ethyl acetate. The organic phase was washed with brine and dried over $\mathrm{MgSO}_{4}$. The crude product of ethyl ester $(548 \mathrm{mg})$ as a yellow oil was obtained after evaporation. Then, the ethyl ester was dissolved in $200 \mathrm{~mL}$ of ethylenediamine, and incubated at $60{ }^{\circ} \mathrm{C}$ for $24 \mathrm{~h}$. The reaction mixture was concentrated in vacuo, and washed with diethyl ether. The white solid 5 (589 mg, $0.103 \mathrm{mmol}, 25 \%$ ) was precipitated in methanol $(100 \mathrm{~mL})$ by adding $35-37 \% \mathrm{HCl}(10 \mathrm{~mL}):{ }^{1} \mathrm{H} \mathrm{NMR}\left(\mathrm{D}_{2} \mathrm{O}\right.$, $400 \mathrm{MHz}$ ) $\delta 3.46-3.08$ (brs, 288H), 2.52 (brs, 16H), 1.43 (brs, $16 \mathrm{H}), 0.51$ (brs, $16 \mathrm{H}):{ }^{13} \mathrm{C}$ NMR $\left(\mathrm{D}_{2} \mathrm{O}\right) \delta 174.3,173.3,58.9$, 58.3, 41.9, 39.2, 39.0, 36.8, 36.6, 19.6, 10.0: ${ }^{29} \mathrm{Si}$ NMR $\left(\mathrm{D}_{2} \mathrm{O}\right.$, $80 \mathrm{MHz}) \delta-65.7$ : ESI-TOF-MS calcd. for $\left[(\mathrm{M}+6 \mathrm{H})^{6+}\right]$ 946.8, found 945.4.

\section{POSS(G3.5) (6)}

To a suspension of $\mathbf{5}(589 \mathrm{mg}, 0.103 \mathrm{mmol})$ and diisopropylamine $(15 \mathrm{~mL}, 86.1 \mathrm{mmol})$ in DMF $(100 \mathrm{~mL})$, tert-butyl bromoacetate $(15 \mathrm{~mL}, 102 \mathrm{mmol})$ was added, and the reaction mixture was stirred at $60^{\circ} \mathrm{C}$ for $16 \mathrm{~h}$. The resulting mixture was concentrated in vacuo, and then, added to $100 \mathrm{~mL}$ of formic acid followed by reflux for $24 \mathrm{~h}$. The reaction mixture was concentrated in vacuo, and poured into $200 \mathrm{~mL}$ of methanol. The compound 6 ( $169 \mathrm{mg}, 0.016 \mathrm{mmol}, 16 \%$ ) was precipitated as a white solid; ${ }^{1} \mathrm{H}$ NMR $\left(\mathrm{D}_{2} \mathrm{O}, 400 \mathrm{MHz}\right) \delta 3.96(\mathrm{~s}, 224 \mathrm{H})$, 3.82 (brs, 96H), 3.35 (brs, 96H), 3.23 (brs, 16H), 1.72 (brs, $16 \mathrm{H}), 0.65$ (brs, $16 \mathrm{H}):{ }^{13} \mathrm{C}$ NMR $\left(\mathrm{D}_{2} \mathrm{O}, 100 \mathrm{MHz}\right) \delta 165.5$, 164.1, 164.0, 51.9, 51.2, 50.9, 48.7, 46.6, 45.7, 42.7, 36.9, 28.9, 10.7: ${ }^{29} \mathrm{Si} \mathrm{NMR}\left(\mathrm{D}_{2} \mathrm{O}, 80 \mathrm{MHz}\right) \delta-67.3$ : ESI-TOF $\left[(\mathrm{M}+7 \mathrm{H})^{7+}\right]$ calcd. 1342.1, found 1342.2.

\section{Complexation with $\mathbf{G d}^{3+}$}

An excess volume of $\mathrm{GdCl}_{3}$ was added to a solution of POSS-core dendrimers. After $1 \mathrm{~h}$ stirring at room temperature, the mixture was dialyzed with Slide-A-Lyzer ${ }^{\circledR}$ Dialysis Cassettes in water. The Gd content of the complex was determined by extrapolating the obtained fluorescence intensity of $\mathrm{Gd}^{3+}$ in the sample to the standard curve with X-ray fluorescence spectroscopy (XRF).

\section{Determination of the Complex Stability Constant $\boldsymbol{K}_{\mathbf{G d L}(\text { Thermo) }}$}

All experiments for determining the complex stability of POSS(G1.5) with $\mathrm{Gd}^{3+}$ were according to the previous work. ${ }^{6}$ From the spectrophotometric titration data, the equilibrium constant of POSS(G1.5) was determined by the reaction of 1 for $\mathrm{Gd}^{3+}$. Using the stability constants of the Arsenazo-III complexes, the calculations of the conditional stability constants $\left(K_{\mathrm{GdL}(\mathrm{Cond})}\right)$ of the complexes at $\mathrm{pH} 4.0$ were made. By using eq 2 , the thermodynamic stability constants $\left(K_{\mathrm{GdL} \text { (Thermo) }}\right)$ were calculated from $K_{\mathrm{GdL}(\mathrm{Cond})}$ and the stepwise ligand protonation constants $\left(K_{\mathrm{n}}\right)$. The $K_{\mathrm{n}}$ values were employed from those of EDTA. ${ }^{6}$

$$
\begin{aligned}
\mathrm{GdAz}_{\mathrm{n}}+\mathrm{L} \Leftrightarrow & \mathrm{GdL}+\mathrm{nAz} \\
K_{\mathrm{GdL}(\text { Thermo })}= & K_{\mathrm{ML}(\mathrm{Cond})}\left(1+K_{1}\left[\mathrm{H}^{+}\right]+K_{1} K_{2}\left[\mathrm{H}^{+}\right]^{2}+\cdots\right. \\
& \left.+K_{\mathrm{n}}\left[\mathrm{H}^{+}\right]^{\mathrm{n}}\right)
\end{aligned}
$$




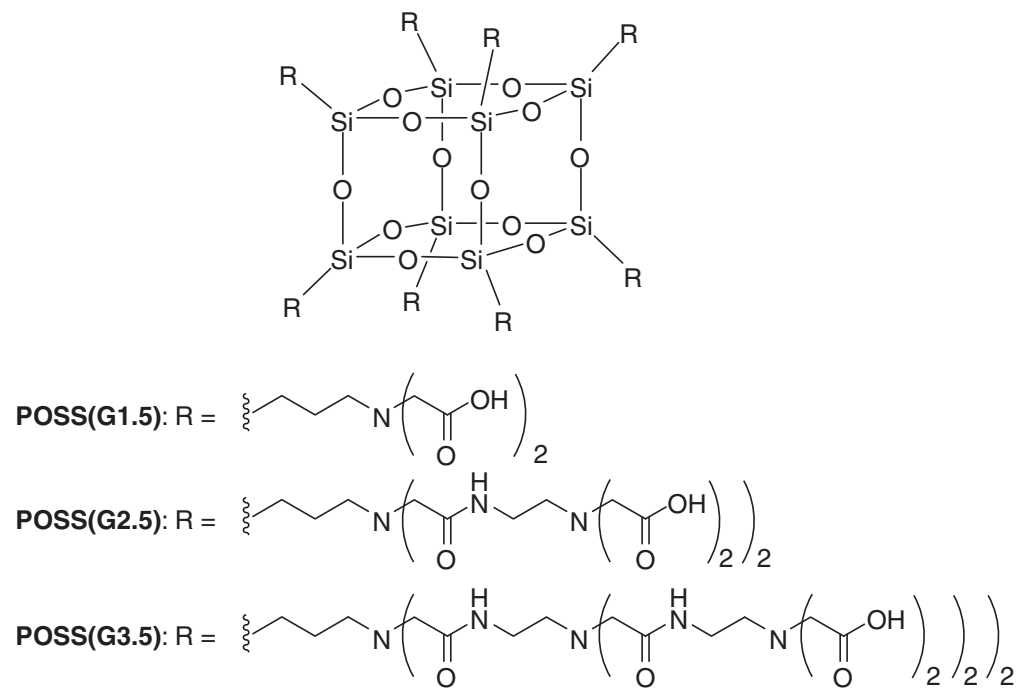

Figure 1. The chemical structures of POSS-core dendrimers.

\section{Isothermal Titration Calorimetry (ITC)}

ITC measurements were performed on a Microcal Omega titration calorimeter. An aqueous solution of $\mathrm{GdCl}_{3}(1 \mathrm{mM})$ was injected stepwise $(10 \mu \mathrm{L} \times 24)$ into a $50 \mu \mathrm{M}$ aqueous solution of the dendrimer. All measurements were conducted at $25^{\circ} \mathrm{C}$. The measured heat flow was recorded as a function of time and converted into enthalpy by integration of the appropriate reaction peaks. The number of $\mathrm{Gd}$ ions binding to POSS(G1.5) was determined by applying a sequential-site model using Origin software (MicroCal Inc.).

\section{MR Imaging}

MR imaging of the samples was carried out using a 7 Tesla Unity Inova MR Scanner (Varian, Palo Alto, CA). Coronal images of the samples were obtained with a $T_{1}$-weighted spinecho sequence. (Repetition time $\left(T_{\mathrm{R}}\right) 25 \mathrm{~ms}$, echo time $\left(T_{\mathrm{E}}\right)$ $12 \mathrm{~ms}$, the field of view was $40 \mathrm{~mm}$, with an image matrix of $256 \times 256$. Slice thickness was $3 \mathrm{~mm}$.)

\section{Relaxivity}

The proton relaxivities of each $\mathrm{Gd}$ complex were calculated from the solvent longitudinal relaxation time $\left(T_{1}\right)$ obtained from the inversion recovery method for the Gd complexes in distilled water. $^{7}$

\section{Cell Viability Assay}

Primary mouse hepatocytes were used to test the toxic effects of various samples as assessed in the 3-[4,5-dimethylthiazol-2-yl]-2,5-diphenyltetrazolium bromide (MTT) assay. Cells were grown in Dulbecco's modified Eagle's medium (DMEM) containing 10\% fetal bovine serum and incubated at $37^{\circ} \mathrm{C}$ in humidified $5 \% \mathrm{CO}_{2} .1 \mathrm{~d}$ before $\mathrm{Gd}$ complex treatment, mouse primary hepatocytes were prepared by the method of collagenase perfusion ${ }^{8}$ and were seeded at a 15,000 cells/ $100 \mu \mathrm{l} /$ well in 96 well microtiter plates. $3 \mathrm{~d}$ after the cells were incubated with Gd complexes, $10 \mu \mathrm{l}$ of $5 \mathrm{mg} / \mathrm{mL}$ MTT in phosphate buffered saline was added to each well, and the plates were kept in a $\mathrm{CO}_{2}$ incubator for an additional $4 \mathrm{~h}$. After MTT solution was removed, the cells were lysed by adding $100 \mu \mathrm{l}$ of $10 \%$ SDS, $0.01 \mathrm{M} \mathrm{NH} \mathrm{NH}_{4} \mathrm{Cl}$ and were incubated overnight. The degree of MTT reduction (i.e., cell viability) in each sample was subsequently assessed by measuring absorption at $600 \mathrm{~nm}$ at $37^{\circ} \mathrm{C}$ using a plate reader. The absorbances measured from the three wells were averaged, and the percentage MTT reduction was calculated by dividing this average by the absorbance measured from a control sample lacking Gd complexes.

\section{Measurements of $\tau_{R}$ Values with ${ }^{2} \mathrm{H}$ NMR}

${ }^{2} \mathrm{H}$ NMR spectra were obtained on JEOL ECX400P NMR spectroscopy operating at $60 \mathrm{MHz}$. All of the longitudinal relaxation time $\left(T_{1}\right)$ measurements were performed using the standard inversion-recovery method. The temperature inside the probe was maintained at $25^{\circ} \mathrm{C} \pm 0.2^{\circ} \mathrm{C}$ by passing a steady flow of air over the sample. The concentrations of each Gd complex were $10 \mathrm{mM}$. Actual $T_{1}$ calculations were performed using the null-point method. The $\tau_{R}$ values were calculated. ${ }^{9}$

The relaxation rate is directly related to the rotational correlation time (eq 3). The quadrupolar coupling constant $\left(e^{2} q Q / \hbar\right)$ depends on the hybridization state of the $\mathrm{C}$-atom carrying the ${ }^{2} \mathrm{H}$-atom; its value is $c a .170 \mathrm{kHz}$ in the case of an $\mathrm{sp}^{3} \mathrm{C}$-atom. ${ }^{10}$

$$
\frac{1}{T_{1}}=\frac{3}{8}\left(\frac{e^{2} q Q}{\hbar}\right)^{2} \tau_{\mathrm{R}}
$$

\section{RESULTS AND DISCUSSION}

The chemical structures and synthetic scheme of the POSScore dendrimers $(\operatorname{POSS}(\mathrm{Gn}), \mathrm{n}=1.5,2.5$, or 3.5) are shown in Figure 1 and Scheme 1. According to DTPA, the POSS-core dendrimers were designed for capturing lanthanide ions with 


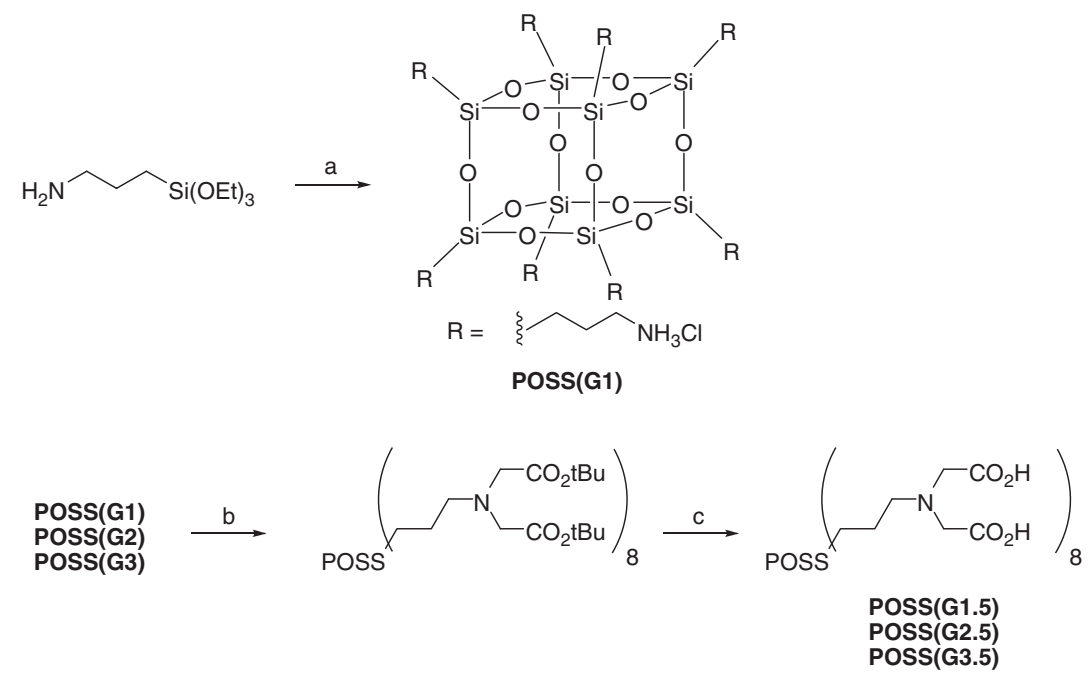

for increasing the generation number

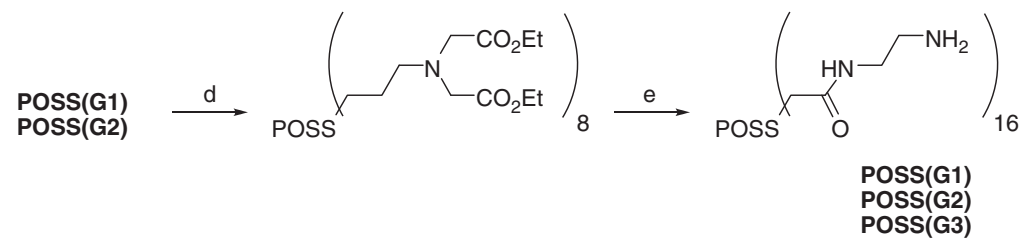

Scheme 1. aReagents: (a) 3-Aminopropyltriethoxysilane, methanol, 35-37\% hydrochloric acid, 30\%; (b) tert-butyl bromoacetate, diisopropylethylamine, dimethylformamide; (c) formic acid, $16 \%$ for POSS(G1.5), $60 \%$ for POSS(G2.5), and 16\% for POSS(G3.5) in two steps, respectively; (d) ethyl bromoacetate, diisopropylethylamine, dimethylformamide; (e) ethylenediamine $61 \%$ for POSS(G2.0) and $25 \%$ for POSS(G3.0) in two steps, respectively.

high affinity. We synthesized the POSS-core dendrimers of generation $1.5,2.5$, and 3.5 possessing carboxylic acid ends in good yields. Each POSS-core dendrimer was identified by NMR and MS spectrometries, and defect of the dendrons estimated from the ${ }^{1} \mathrm{H}$ NMR spectrum was less than 5\%. From the X-ray fluorescence measurements with the residue after the complexation followed by dialysis in water, it was revealed that $\operatorname{POSS}(\mathrm{Gn})(\mathrm{n}=1.5,2.5$, and 3.5) formed complexes with two, four, and eight $\mathrm{Gd}^{3+}$ ions, respectively. The number of $\mathrm{Gd}$ ions in the complex with $\operatorname{POSS}(\mathrm{G} 1.5)$ was also determined as two from the curve fitting of the isothermal titration calorimetry spectra. ${ }^{11}$ The stability constant of the Gd complex with POSS(G1.5) was evaluated to be 20.0 with the spectrophotometric method using the Arsenazo-III complex. ${ }^{12}$ From the MTT assay with the primary hepatocytes, the cytotoxicity of $\left[\mathrm{Gd}_{2} \mathrm{POSS}(\mathrm{G} 1.5)\right]^{2-}$ was similar to that of the $[\mathrm{Gd}(\mathrm{DOTA})]^{-}$ complex (Figure 2). Although the stability of the Gd complex with POSS(G1.5) is relatively lower than that of DOTA (25.3) and DTPA (22.2), ${ }^{6}$ these results suggest that less significant discharging of $\mathrm{Gd}^{3+}$ from the Gd-POSS-core dendrimer complex could occur under biological conditions.

Figure 3 shows the MR images of the solutions containing each Gd complex of POSS(G1.5) $\left(\left[\mathrm{Gd}_{2} \mathrm{POSS}(\mathrm{G} 1.5)\right]^{2-}\right)$, POSS(G2.5) ([Gd $\left.\left.{ }_{4} \mathrm{POSS}(\mathrm{G} 2.5)\right]^{4-}\right), \operatorname{POSS}(\mathrm{G} 3.5)\left(\left[\mathrm{Gd}_{8} \mathrm{POSS}-\right.\right.$ $\left.(\mathrm{G} 3.5)]^{8-}\right)$, DOTA ([Gd(DOTA) $\left.]^{-}\right)$, and DTPA ([Gd(DTPA) $]^{2-}$ ) at $7 \mathrm{~T}$. From the $T_{1}$-weighted images, detection limits of the $\mathrm{Gd}$ complexes were evaluated. The proton

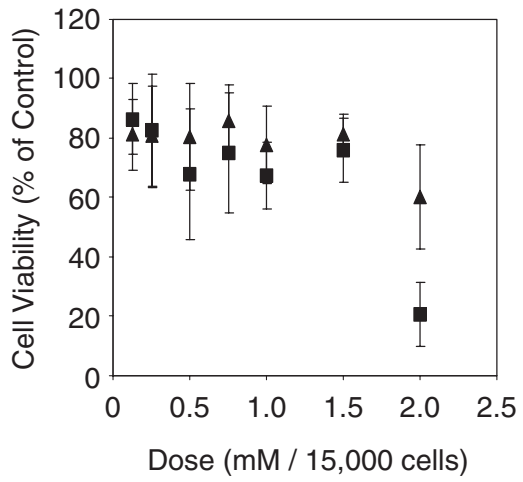

Figure 2. Effect of [Gd2POSS(G1.5)] ${ }^{2-}$ (triangular dots) and [Gd(DOTA)](square dots) on the viability of primary hepatocytes. Cells were incubated with various concentrations of the Gd complexes for $72 \mathrm{~h}$. Results are expressed as viability (\% viable cells in comparison with the control) versus complex concentration. Each experiment was performed in triplicate twice and the error bars represent SD values.

relaxivity $\left(\mathrm{r}_{1}\right)$ of each Gd complex was determined from the $T_{1}$ measurements (Figure 4). ${ }^{13}$ The contrasts obtained from $[\operatorname{Gd}(D O T A)]^{-}$and $[\operatorname{Gd}(D T P A)]^{2-}$, which are common clinically used contrast agents, can not be discriminated from water below $250 \mu \mathrm{M}$ concentrations. On the other hand, the $\mathrm{Gd}$ complexes of the POSS-core dendrimers gave much clearer contrast even at $30 \mu \mathrm{M} \operatorname{POSS}(\mathrm{G} 1.5)$ or at $4 \mu \mathrm{M} \operatorname{POSS}(\mathrm{G} 2.5)$ and POSS $(\mathrm{G} 3.5)$. It means that the sensitivity of the POSS-core 


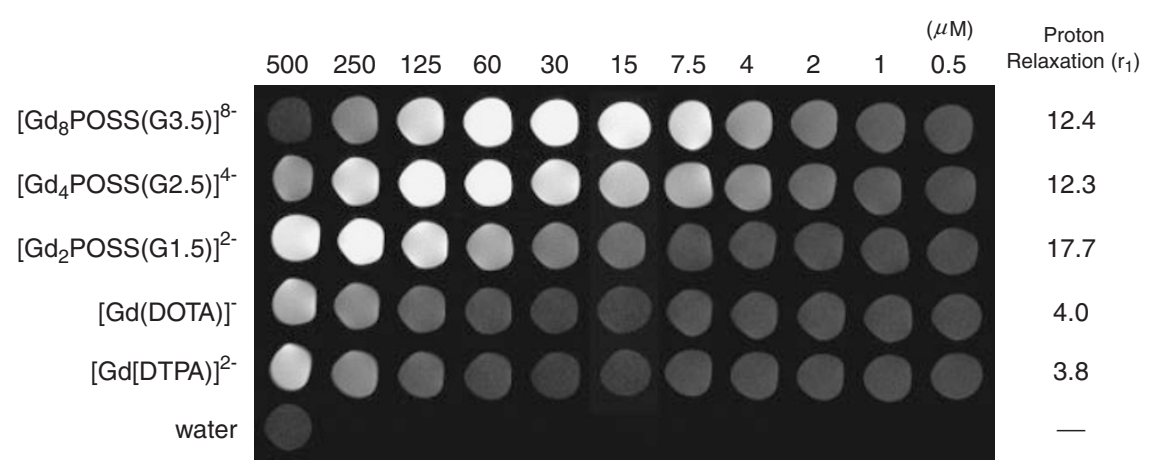

Figure 3. MR imaging of various concentrated $\mathrm{Gd}$ complexes and their proton relaxivity. All samples were sealed into $5 \mathrm{~mm}$ of glass tubes, and $T_{1}$-weighted phantom image was taken at $7 \mathrm{~T}$ at $25^{\circ} \mathrm{C}$. The relaxivity $r_{1}$ was calculated from the slope of $T_{1}$ dependency on the concentration of the paramagnetic species at $7 \mathrm{~T}$.
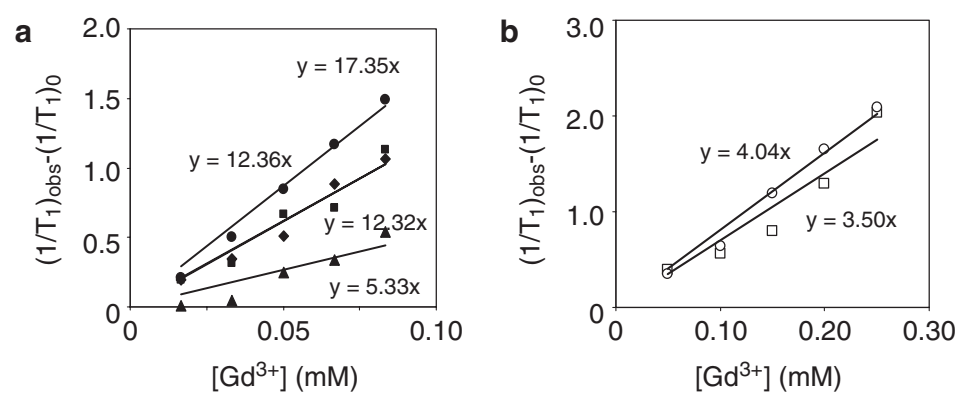

Figure 4. $T_{1}$ dependency on $\mathrm{Gd}^{3+}$ concentration, (a) $\left[\mathrm{Gd}_{2} \mathrm{POSS}(\mathrm{G} 1.5)\right]^{2-}$ (circular dots), $\left[\mathrm{Gd}_{4} \mathrm{POSS}(\mathrm{G} 2.5)\right]^{4-}$ (rhombic dots), [Gd 8 POSS(G3.5) $]^{8-}$ (square dots), and $\left[\mathrm{Gd}_{2} \mathrm{PAMAM}(\mathrm{G} 1.5)\right]^{2-}$ (triangular dots), (b) [Gd(DOTA)]- (circular dots) and [Gd(DTPA) $]^{2-}$ (square dots). The Gd complexes were dissolved in deionized water, and $T_{1}$ values were measured at $25^{\circ} \mathrm{C}$. The proton relaxivity $r_{1}$ was determined by the slope of the linear approximation.

dendrimer to obtain positive contrasts was improved approximately 100-times larger than those of DOTA and DTPA at $7 \mathrm{~T}$.

The addition of generations, followed by the increase of molecular weights, to the dendrimer-based $\mathrm{Gd}$ complexes showed the strong enhancement to the relaxivity. ${ }^{2 a, 14}$ Interestingly, the $r_{1}$ value of the $\left[\mathrm{Gd}_{2} \operatorname{POSS}(\mathrm{G} 1.5)\right]^{2-}\left(M_{\mathrm{w}}=2117\right)$ showed 3-times larger than that of the G1.5 polyamidoamine dendrimer $\left(M_{\mathrm{w}}=2889, \mathrm{r}_{1}=5.3 \mathrm{mM}^{-1} \mathrm{~s}^{-1}\right)$. From previous works, the rigid structure in the Gd complexes can affect the rotational mobility, and the relaxivity was improved without significant increase of the molecular weights. ${ }^{3}$ Our results imply that the internal rigidity of the POSS core could provide similar effect to the Gd complexes of the POSS-core dendrimers. This assumption was supported by the decrease of the $r_{1}$ values of $\left[\mathrm{Gd}_{4} \operatorname{POSS}(\mathrm{G} 2.5)\right]^{4-} \quad\left(M_{\mathrm{w}}=4953\right)$ and $\left[\mathrm{Gd}_{8} \mathrm{POSS}(\mathrm{G} 3.5)\right]^{8-}\left(M_{\mathrm{w}}=10627\right)$, in which the internal rigidity of the POSS core might be less influenced due to the long chain of the dendrons.

In order to evaluate the molecular rotation of the $\mathrm{Gd}$ complexes, we compared the rotational correlation time $\tau_{R}$ of the $\left[\mathrm{Gd}_{2} \mathrm{POSS}(\mathrm{G} 1.5)\right]^{2-}$ with those of $[\mathrm{Gd}(\mathrm{DOTA})]^{-}$and $[\mathrm{Gd}(\mathrm{DTPA})]^{2-}$. The $\tau_{\mathrm{R}}$ values of the $\mathrm{Gd}$ complexes were determined by ${ }^{2} \mathrm{H}$ NMR spectroscopy using the Gd complexes deuterated in the $\alpha$-position to the carboxylate groups. ${ }^{9,15}$ From our experiments, the $\tau_{R}$ value of $\left[\mathrm{Gd}_{2} \operatorname{POSS}(\mathrm{G} 1.5)\right]^{2-}\left(\tau_{\mathrm{R}}=\right.$ $2251 \mathrm{ps})$ was approximately 11-times higher than that of $[\mathrm{Gd}(\mathrm{DTPA})]^{2-}\left(\tau_{\mathrm{R}}=199 \mathrm{ps}\right)$. Compared to those of $[\mathrm{Gd}(\mathrm{DTPA})]^{2-}$ and $[\mathrm{Gd}(\mathrm{DOTA})]^{-}$obtained from other workers (58 and $77 \mathrm{ps,}$ respectively), the $\tau_{\mathrm{R}}$ value for $\left[\mathrm{Gd}_{2} \text { POSS }(\mathrm{G} 1.5)\right]^{2-}$ showed at least 20-fold larger. ${ }^{9,16}$ These results suggest that $\mathrm{Gd}^{3+}$ in $\left[\mathrm{Gd}_{2} \mathrm{POSS}(\mathrm{G} 1.5)\right]^{2-}$ could be highly restricted to rotate. It can be summarized that the POSS core could contribute to the lower tumbling mode of the Gd complexes of the POSS-core dendrimers, and consequently the efficient proton relaxation of water tissue could take place.

\section{CONCLUSION}

In conclusion, we report the effect of the core on the proton longitudinal relaxation of water tissue using the POSS-core dendrimers as novel Gd chelators. The relaxivity measurements revealed that the POSS core played a crucial role in the enhancement of the proton longitudinal relaxation of water tissue in the dendrimers. In addition, compared to the $\mathrm{Gd}$ complexes with DTPA and DOTA, the observed detection limits of POSS-core dendrimers for the positive contrast can be improved approximately 100-fold in the MR image at the strong magnetic field. Although the structural information should be continued to study, our findings described here should be available for designing novel Gd-based contrast agents, as well as for enhancing the relaxivity of previous ones. The POSS-core dendrimers are promised to be a platform for constructing new MR probes. 
Acknowledgment. This study was conducted as a part of the project, "R\&D of Molecular Imaging Equipment for Malignant Tumor Therapy Support," supported by NEDO (New Energy and Industrial Technology Development Organization). We thank Prof. Y. Tsuji and Dr. T. Fujiwara for the measurement of ${ }^{2} \mathrm{H}$ NMR. We thank Prof. I. Hamachi and Mr. S. Fujishima (Kyoto University) for the measurements of isothermal titration calorimetry (ITC). We thank Prof. S. Kimura and Dr. A. Makino (Kyoto University) for the measurements of the $\mathrm{pH}$ titration.

Received: October 27, 2008

Accepted: December 22, 2008

Published: February 12, 2009

\section{REFERENCES}

1. a) K. W.-Y. Chan and W.-T. Wong, Coord. Chem. Rev., 251, 2428 (2007).

b) P. Caravan, Chem. Soc. Rev., 35, 512 (2006).

c) M. Bottrill, L. Kwok, and N. J. Long, Chem. Soc. Rev., 35, 557 (2006).

d) P. Caravan, J. J. Ellison, T. J. McMurry, and R. B. Lauffer, Chem. Rev., 99, 2293 (1999).

2. a) S. Langereis, A. Dirksen, T. M. Hacheng, M. H. P. van Genderen, and E. W. Meijer, New J. Chem., 31, 1152 (2007).

b) D. L. Ladd, R. Hollister, X. Peng, D. Wei, G. Wu, D. Delecki, R. A. Snow, J. L. Toner, K. Kellar, J. Eck, V. C. Desai, G. Raymond, L. B. Kinter, T. S. Desser, and D. L. Rubin, Bioconjugate Chem., 10, 361 (1999).

c) M. G. Duarte, M. H. Gil, J. A. Peters, J. M. Colet, L. Vander Elst, R. N. Muller, and C. F. G. C. Geraldes, Bioconjugate Chem., 12, 170 (2001).

d) M. J. Allen, R. T. Raines, and L. L. Kiessling, J. Am. Chem. Soc., 128, 6534 (2006).

e) Z. Jászberényi, L. Moriggi, P. Schmidt, C. Weidensteiner, R. Kneuer, A. E. Merbach, L. Helm, and É. Tóth, J. Biol. Inorg. Chem., 12, 406 (2007).

f) D. A. Falton, E. M. Elemento, S. Aime, L. Chaabane, M. Botta, and D. Parker, Chem. Commun., 1064 (2006).

g) L. H. Bryant, M. W. Jr, Brechbiel, C. Wu, J. W. M. Bulte, V. Herynek, and J. A. Frank, J. Magn. Reson. Imaging, 9, 348 (1999).

3. a) J. Paris, C. Gameiro, V. Humblet, P. K. Mohapatra, V. Jacques, and J. F. Desreux, Inorg. Chem., 45, 5092 (2006).

b) J. Rudovský, P. Hermann, M. Botta, S. Aime, and I. Lukeš, Chem. Commun., 2390 (2005).

c) G. M. Nicolle, É. Tóth, H. Schmitt-Willich, B. Radüchel, and A. E.
Merbach, Chem. Eur. J., 8, 1040 (2002).

d) Z. Zhang, M. T. Greenfield, M. Spiller, T. J. Mcmurry, R. B. Lauffer, and P. Caravan, Angew. Chem., Int. Ed., 44, 6799 (2005).

4. a) R. M. Laine, J. Choi, and I. Lee, Adv. Mater., 13, 800 (2001). b) M. G. Voronkov and V. I. Lavrent'yev, Top. Curr. Chem., 102 (1982).

c) K. Tanaka, N. Kitamura, K. Naka, and Y. Chujo, Chem. Commun., in press (2008).

d) K. Naka, M. Fujita, K. Tanaka, and Y. Chujo, Langmuir, 23, 9057 (2007).

e) K. Tanaka, K. Inafuku, K. Naka, and Y. Chujo, Org. Biomol. Chem., 6, 3899 (2008).

f) K. Tanaka, K. Inafuku, and Y. Chujo, Bioorg. Med. Chem., in press (2008).

5. a) M.-C. Gravel and R. M. Laine, Polym. Prepr. (Am. Chem. Soc. Div. Polym. Chem.), 38, 155 (1997).

b) F. J. Feher and K. D. Wyndham, Chem. Commun., 323 (1998).

c) M.-C. Gravel, C. Zhang, M. Dinderman, and R. M. Laine, Appl. Organometal. Chem., 13, 329 (1999).

6. K. Kumar, C. A. Chang, L. C. Francesconi, D. D. Dischino, M. F. Malley, J. Z. Gougoutas, and M. F. Tweedle, Inorg. Chem., 33, 3567 (1994).

7. R. B. Lauffer, Chem. Rev., 87, 901 (1987).

8. P. O. Seglen, in "Methods in Cell Biology," 2nd ed., D. M. Preseon, Ed., vol. 13, Academic Press, New York, 1976, chap. 4, p 29.

9. S. Laurent, L. Vander Elst, S. Houźe, N. Guérit, and R. N. Muller, Helv. Chim. Acta, 83, 394 (2000).

10. H. H. Mantsch, H. Saito, and I. C. Smith, Prog. Nucl. Magn. Reson. Spectrosc., 11, 211 (1977).

11. K. Naka, M. Fujita, K. Tanaka, and Y. Chujo, Langmuir, 23, 9057 (2007).

12. a) M. F. Loncin, J. F. Desreux, and E. Merciny, Inorg. Chem., 25, 2646 (1986).

b) M. Kodama, T. Koike, A. B. Mahatma, and E. Kimura, Inorg. Chem., 30, 1270 (1991).

c) C. G. Pippin, T. A. Parker, T. J. McMurry, and M. W. Brechbiel, Bioconjugate Chem., 3, 342 (1992).

13. a) B. P. Hay, E. J. Werner, and K. N. Raymond, Bioconjugate Chem., 15, 1496 (2004).

b) J. L. Pascual-Ahuir, I. Tunon, and E. Silla, J. Comput. Chem., 15, 1127 (1994).

c) L. A. Castonguay, A. M. Treasurywala, T. J. Caulfield, E. P. Jaeger, and K. E. Kellar, Bioconjugate Chem., 10, 958 (1999).

14. E. C. Wiener, M. W. Brechbiel, H. Brothers, R. L. Magin, O. A. Gansow, D. A. Tomalia, and P. C. Lauterbur, Magn. Reson. Med., 31, 1 (1994).

15. A. D. Meltzer and D. A. Tirrell, Macromolecules, 25, 4549 (1992).

16. T.-M. Lee, T.-H. Cheng, M.-H. Ou, C. A. Chang, G.-C. Liu, and Y.-M. Wang, Magn. Reson. Chem., 42, 329 (2004). 